\title{
Hydrogen Oxidation on Gas Diffusion Electrodes for Phosphoric Acid Fuel Cells in the Presence of Carbon Monoxide and Oxygen
}

\author{
Gang, Xiao; Li, Qingfeng; Hjuler, Hans Aage; Bjerrum, Niels
}

Published in:

Journal of The Electrochemical Society

Link to article, DOI:

$10.1149 / 1.2048660$

Publication date:

1995

Document Version

Publisher's PDF, also known as Version of record

Link back to DTU Orbit

Citation (APA):

Gang, X., Li, Q., Hjuler, H. A., \& Bjerrum, N. (1995). Hydrogen Oxidation on Gas Diffusion Electrodes for Phosphoric Acid Fuel Cells in the Presence of Carbon Monoxide and Oxygen. Journal of The Electrochemical Society, 142(9), 2890-2893. https://doi.org/10.1149/1.2048660

\section{General rights}

Copyright and moral rights for the publications made accessible in the public portal are retained by the authors and/or other copyright owners and it is a condition of accessing publications that users recognise and abide by the legal requirements associated with these rights.

- Users may download and print one copy of any publication from the public portal for the purpose of private study or research.

- You may not further distribute the material or use it for any profit-making activity or commercial gain

- You may freely distribute the URL identifying the publication in the public portal 
18. D. Aurbach and A. Zaban, J. Electroanal. Chem., 367, 15 (1994).
19. D. Aurbach, A. Zaban, I. Weissman, and O. Chusid, Electrochim. Acta, 39, 51 (1994).

\title{
Hydrogen Oxidation on Gas Diffusion Electrodes for Phosphoric Acid Fuel Cells in the Presence of Carbon Monoxide and Oxygen
}

\author{
Xiao Gang, ${ }^{*}$ Li Qingfeng, ${ }^{*}$ Hans Aage Hjuler," and Niels J. Bjerrum* \\ Materials Science Group, Chemistry Department A, Technical University of Denmark, DK-2800 Lyngby, Denmark
}

\begin{abstract}
Hydrogen oxidation has been studied on a carbon-supported platinum gas diffusion electrode in a phosphoric acid electrolyte in the presence of carbon monoxide and oxygen in the feed gas. The poisoning effect of carbon monoxide present in the feed gas was measured in the temperature range from 80 to $150^{\circ} \mathrm{C}$. It was found that throughout the temperature range, the potential loss due to the CO poisoning can be reduced to a great extent by the injection of small amounts of gaseous oxygen into the hydrogen gas containing carbon monoxide. By adding 5 volume percent (v/o) oxygen, an almost $\mathrm{CO}$-free performance can be obtained for carbon monoxide concentrations up to $0.5 \mathrm{v} / \mathrm{o} \mathrm{CO}$ at $130^{\circ} \mathrm{C}, 0.2 \mathrm{v} / \mathrm{o} \mathrm{CO}$ at $100^{\circ} \mathrm{C}$, and $0.1 \mathrm{v} / \mathrm{o} \mathrm{CO}$ at $80^{\circ} \mathrm{C}$, respectively.
\end{abstract}

\section{Introduction}

The hydrogen electrode reaction is very reversible in acid electrolytes. Its electrochemical performance is generally excellent in fuel cells. The overpotential at the operating current densities in fuel cells, e.g., 200 to $400 \mathrm{~mA} / \mathrm{cm}^{2}$, is only ca. $20 \mathrm{mV}$ for either phosphoric acid fuel cells (PAFC) at $190^{\circ} \mathrm{C}$ or for solid polymer electrolyte fuel cells (SPEFC) at $80^{\circ} \mathrm{C}$. In the fuel cells using molten carbonate (MCFC) or solid oxide electrolyte (SOFC), the overpotential at the hydrogen electrode is even smaller due to the extremely high operating temperature $\left(650^{\circ} \mathrm{C}\right.$ for $\mathrm{MCFC}$ and $1000^{\circ} \mathrm{C}$ for SOFC).

The major problem at the hydrogen electrode, however, is to eliminate the poisoning effect due to impurities such as $\mathrm{CO}, \mathrm{H}_{2} \mathrm{~S}$, and $\mathrm{SO}_{2}$. These impurities are generally present more or less in the fuel hydrogen produced either by reforming of natural gas or by coal gasification. Carbon monoxide, among these impurities, is the most challenging one for noble metal electrocatalysts in acid electrolytes.

The poisoning effect of platinum catalysts by carbon monoxide has been intensively studied by many investigators in the field of fuel cells and electrocatalysts. ${ }^{1-11}$ These studies have mainly been concentrated on the mechanism of adsorption and oxidation and the nature of the absorbed species on the noble metal electrodes in various acid electrolytes. ${ }^{1-8}$ Two kinds of adsorption mechanisms have been proposed, i.e., the linearly and bridge or multibonded $\mathrm{CO}$ species. ${ }^{2-8}$ As assumed, the linearly absorbed carbon monoxide species, - $\mathrm{CO}$, involve one adsorption site per $\mathrm{CO}$ particle, while the bridge or multibonded carbon monoxide species, $=\mathrm{CO}$, requires two or more adjacent platinum surface sites.

In the case of hydrogen oxidation on a carbon-supported platinum gas-diffusion electrode in the presence of carbon monoxide, the poisoning effect is found to depend logarithmically on the ratio of carbon monoxide concentration to the hydrogen concentration, $[\mathrm{CO}] /\left[\mathrm{H}_{2}\right]$. This indicates that the poisoning is a simple competition with hydrogen for active sites, ${ }^{3,10}$ since the strong chemisorptive bond of the carbon monoxide molecule may lead to a surface blockage from hydrogen oxidation.

The fact that the potential loss of the hydrogen electrode is due to the $\mathrm{CO}$ blocking coverage of the active sites accessible for hydrogen led a number of investigators to corre-

\footnotetext{
* Electrochemicai Society Active Member
}

late the potential loss with the surface coverage of carbon monoxide, $\theta_{\mathrm{co}}$. By measuring the ratio of the current density in the presence of $\mathrm{CO}\left(i_{\mathrm{CO}}\right)$ to that of pure hydrogen $\left(i_{\mathrm{H}_{2}}\right)$ at a given potential in the linear portion of the polarization plots,${ }^{9,10}$ the surface coverage of carbon monoxide can be calculated. The fractional coverage thus obtained was found to follow a Temkin isotherm relationship. By comparing the coverage-concentration relationship of the $\mathrm{CO}$ adsorption with the Temkin isotherm expression, the free energy change and the standard entropy of the CO adsorption were calculated and found to have large negative values, indicating the strong adsorption and the strong favoring at lower temperature. ${ }^{10}$

From the fuel cell point of view, the strong dependence of $\mathrm{CO}$ poisoning on temperature provides a possibility for solving the problem, i.e., raising the operating temperature of the fuel cells. Studies of the CO tolerance for acid fuel cells at different temperatures showed that operating temperatures above $135^{\circ} \mathrm{C}$ are needed to avoid significant potential losses due to carbon monoxide poisoning. One of the main reasons for operating PAFCs at 180 to $190^{\circ} \mathrm{C}$ is to tolerate 1 to $2 \%$ carbon monoxide without significant potential losses or other serious difficulties for the hydrogen oxidation reaction..$^{11-13}$ However, increasing the temperature represents a compromise between lower poisoning and higher rates of corrosion and component degradation, particularly at the cathode. ${ }^{14}$ In the case of the SPEFCs, the operating temperature is typically below $100^{\circ} \mathrm{C}$, since the membrane must not be dehydrated to maintain the conductivity. At such low temperatures, the poisoning problem of carbon monoxide is even more challenging: even very small amounts of carbon monoxide, e.g., 10 to $50 \mathrm{ppm}$, in the hydrogen feeding gas may cause significant potential loss in connection with the hydrogen electrode.

Removal of the low level carbon monoxide is challenging also for the methanol reforming process, because as an alternative solution the CO content in the feed gas can be reduced before it enters the fuel cell. The reforming product gas normally contains carbon monoxide of the level of 1 volume percent (v/o). It has been found ${ }^{15}$ that this $\mathrm{CO}$ level can be reduced by injecting a small amount of oxygen directly into the reformer where noble catalysts are present, since the CO oxidation by molecular oxygen occurs. An extension of the idea has been made by Gottesfeld et $a l .{ }^{16}$ to SPEFCs. By injecting low levels of $\mathrm{O}_{2}$ into the hydrogen feeding stream of a SPEFC, the cell voltage loss 
caused by the poisoning of $100 \mathrm{ppm} \mathrm{CO}$ was sufficiently recovered.

In the present work the hydrogen oxidation on carbon-supported platinum gas-diffusion electrodes has been studied in the presence of both carbon monoxide and oxygen in $100 \% \mathrm{H}_{3} \mathrm{PO}_{4}$ in the temperatures ranging from 80 to $150^{\circ} \mathrm{C}$.

\section{Experimental}

The gas-diffusion electrodes consist of a layer of electrochemically inert carbon paper and an active layer. The active layer consists of a mixture of 60 weight percent $(\mathrm{w} / \mathrm{o})$ platinum supported on Vulcan XC-72 carbon powder (Pt/ $\mathrm{C}=10 \mathrm{w} / \mathrm{o}$ ) and $40 \mathrm{w} / \mathrm{O}$ PTFE as binder. The platinum loading is $0.5 \mathrm{mg} / \mathrm{cm}^{2}$. The electrodes were made by a tape-casting method in this laboratory. ${ }^{17}$

Phosphoric acid (85 w/o, analytical grade, Riedel-de Haën) was purified by treatment with hydrogen peroxide and concentrated to $100 \mathrm{w} / \mathrm{o}$ by heating. The concentration of the acid was checked by density measurements.

An electrochemical half-cell made of PTFE was used to perform the polarization measurements. It consists of a gas-diffusion working electrode (active geometric area was $0.78 \mathrm{~cm}^{2}$ ), a reversible hydrogen reference electrode, and a platinum plate as counterelectrode. Pure gas or gas mixtures were passed through the gas chamber located on the carbon paper side of the electrode, as described elsewhere. ${ }^{18}$ The cell was placed in an oven maintained at the desired temperature $\left( \pm 1^{\circ} \mathrm{C}\right)$.

An electrochemical interface (SI 1286, Schlumberger Technologies, Ltd.) and a potentiostat/galvanostat (Model 273, EG\&G Princeton Applied Research) were used to perform the measurements. The polarization curves were obtained by the current step potentiometry. The chronopotentiometric curves were recorded by computer sampling at each current density applied. The polarization potentials at various current density settings were then taken from these curves when a steady state was reached. The duration for reaching such a steady state varies mainly due to different feeding gas compositions, from $30 \mathrm{~s}$ for pure hydrogen at various current densities to more than half an hour when carbon monoxide is present. A current interruption technique was used for the IR correction. By means of a digital oscilloscope (DSO 1602, Gould Electronic, Ltd.), the IR part of the potential was obtained $30 \mu s$ after the current was interrupted.

Purified hydrogen (>99.998 v/o, Hede Nielsen A/S) and carbon monoxide (>99.98 v/o, Dansk Ilt \& Brintfabrik) were used in the measurements. The gas flow was controlled by means of a mass flow controller (5850TR, Brooks Instrument B. V.).

\section{Results and Discussion}

The hydrogen oxidation process was found to be almost independent of temperature in the presently studied temperature range. For example, at a current density of $400 \mathrm{~mA} / \mathrm{cm}^{2}$, the overpotential difference is less than $5 \mathrm{mV}$ for a temperature variation from 80 to $150^{\circ} \mathrm{C}$. This is due to the fact that the hydrogen electrode is very reversible in the acid electrolyte. When carbon monoxide, however, is present in the hydrogen feeding gas, the overpotential is very temperature dependent. Figure 1 shows polarization curves for the oxidation reaction of hydrogen containing $0.1 \mathrm{v} / 0$ carbon monoxide at different temperatures. In this and the following figures, each point represents the average value of at least three measurements, and different points at the same current densities are from independent measurements in which different pieces of a produced electrode are examined.

At temperatures higher than $130^{\circ} \mathrm{C}$, the increase in overpotential due to the presence of $0.1 \mathrm{v} / \mathrm{o}$ carbon monoxide is between 10 and $15 \mathrm{mV}$ at the operating current densities (200 to $400 \mathrm{~mA} / \mathrm{cm}^{2}$ ) for the fuei cells, as seen from Fig. 1 . When the operating temperature is lower than $110^{\circ} \mathrm{C}$, the poisoning effect is dramatically higher. At a temperature of $80^{\circ} \mathrm{C}$, the typical operating temperature of SPEFCs, for in-

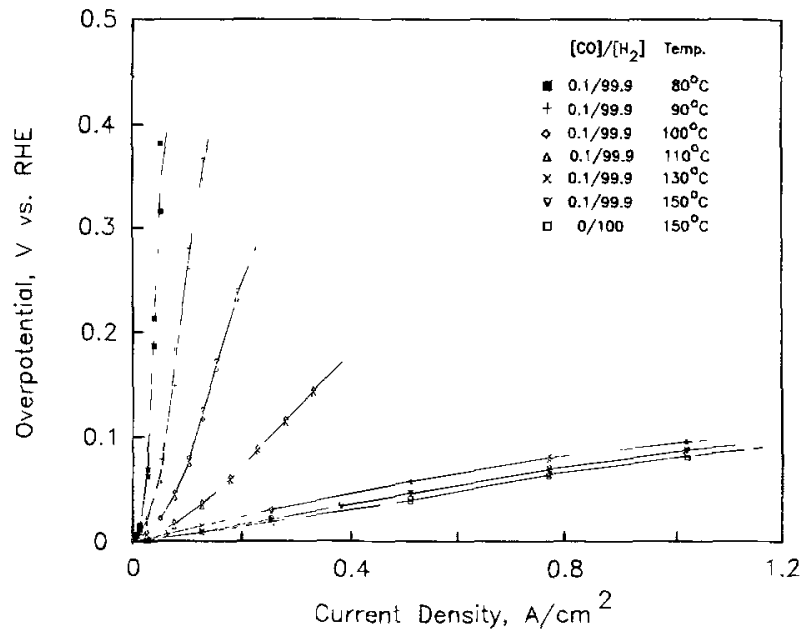

Fig. 1. Polarization curves for hydrogen oxidation in $100 \mathrm{w} / 0$ $\mathrm{H}_{3} \mathrm{PO}_{4}$ when $0.1 \mathrm{v} / 0$ carbon monoxide was added to hydrogen at different temperatures as indicated in the figure.

stance, $0.1 \mathrm{v} / \mathrm{o}$ CO cannot be tolerated due to a polarization of ca. $350 \mathrm{mV}$ at $50 \mathrm{~mA} / \mathrm{cm}^{2}$ (see Fig. 1).

Compared with the above results, Kosek et al., ${ }^{19}$ using an SPEFC at $80^{\circ} \mathrm{C}$, found a considerable voltage loss when $15 \mathrm{ppm}$ carbon monoxide was contained in the hydrogen feeding gas. At the concentration of $1600 \mathrm{ppm}(0.16 \mathrm{v} / \mathrm{o})$ $\mathrm{CO}$, a large polarization of nearly $500 \mathrm{mV}$ at $100 \mathrm{~mA} / \mathrm{cm}^{2}$ was observed. It is rather close to the results obtained in the present work with the phosphoric acid electrolyte at the same temperature.

In Fig. 2a and $3 \mathrm{a}$ are shown polarization plots for hydrogen oxidation at different $[\mathrm{CO}] /\left[\mathrm{H}_{2}\right]$ ratios and at temperatures of 150 and $130^{\circ} \mathrm{C}$, respectively. It is seen that at both temperatures, the potential loss by $\mathrm{CO}$ poisoning increases with increasing ratio between the $\mathrm{CO}$ and $\mathrm{H}_{2}$ concentra-

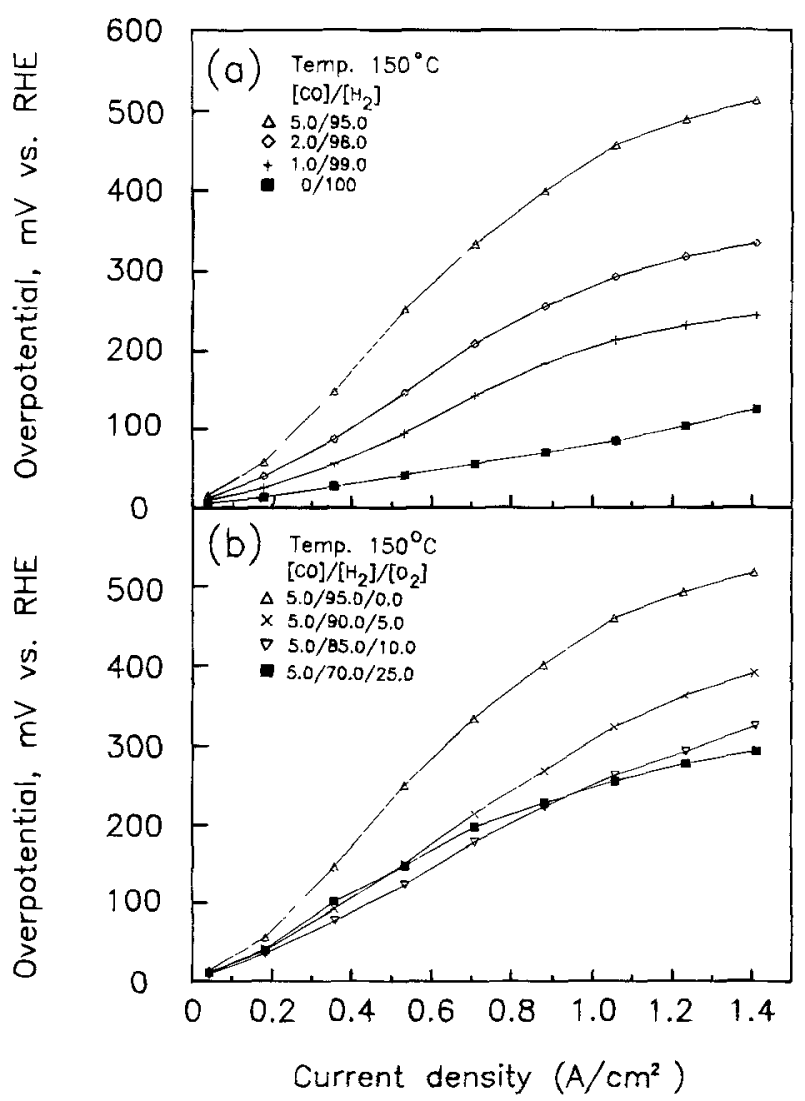

Fig. 2. Polarization curves for hydrogen oxidation in $100 \mathrm{w} / \mathrm{o}$ $\mathrm{H}_{3} \mathrm{PO}_{4}$ at $150^{\circ} \mathrm{C}$. (a) Hydrogen and hydrogen containing $\mathrm{CO}$; (b) mixture of hydrogen and $\mathrm{CO}$ in the presence of $\mathrm{O}_{2}$. 

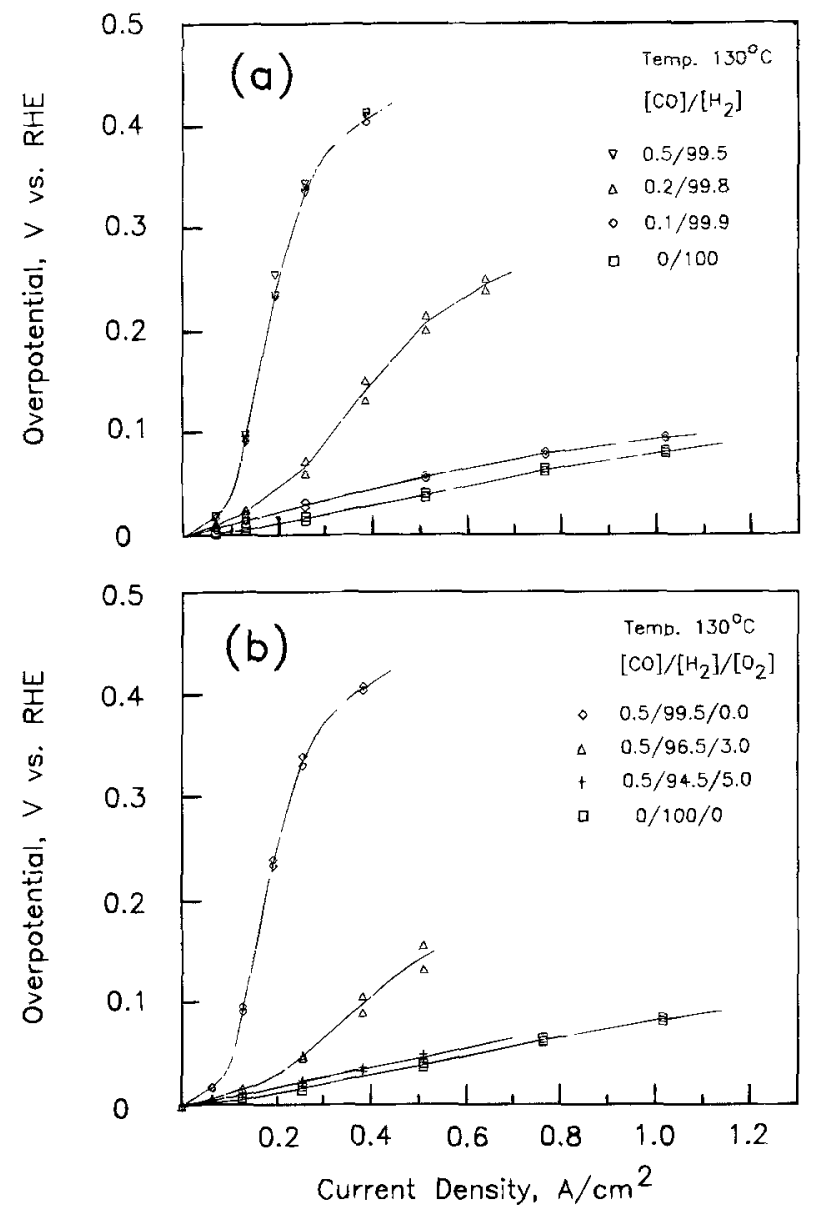

Fig. 3. Polarization curves for hydrogen oxidation in $100 \mathrm{w} / \mathrm{o}$ $\mathrm{H}_{3} \mathrm{PO}_{4}$ at $130^{\circ} \mathrm{C}$. (a) Hydrogen and hydrogen containing $\mathrm{CO}$; (b) mixiure of hydrogen and $\mathrm{CO}$ in the presence of $\mathrm{O}_{2}$.

tions. As shown by Dahr et al., ${ }^{9,10}$ this potential loss, in fact, is linearly dependent on the logarithm of $[\mathrm{CO}] /\left[\mathrm{H}_{2}\right]$ ratio. This indicates that the poisoning effect is caused essentially by the replacement of hydrogen by carbon monoxide at the platinum active surface. At high contents of carbon monoxide, however, the polarization plots display deviations from the linearity at high current densities. The increased poisoning effect indicates that there is a strong interaction of carbon monoxide with the catalyst surface, probably due to a different mechanism of hydrogen replacement or a different bonding of carbon monoxide with platinum.

The simple bonding of carbon monoxide in the steadystate adsorption is expected, ${ }^{2-4.10}$ i.e., the linear CO adsorption occurs either at high temperatures or at lower CO concentrations where linear potential-current density plots were obtained. In this manner each absorbed CO species occupies one surface site on the platinum catalyst. At lower temperatures, however, the adsorption is strongly favored. The increased number of absorbed CO species at the catalyst surface might lead to a mutual repulsion among the absorbed $\mathrm{CO}$ molecules, resulting in the favored orientation of the molecules and therefore an increased potential loss. Some orientation of the CO dipole molecules may also be favored at lower temperatures and at high electrode potentials, so as to strengthen the adsorption of $\mathrm{CO}$ on the platinum surface.

The temperature dependence of carbon monoxide poisoning has also been studied by Kunz ${ }^{11}$ for CO concentration up to $6 \mathrm{v} / \mathrm{o}$ and temperature ranging from 160 to $218^{\circ} \mathrm{C}$, by Stonehart ${ }^{20}$ for $\mathrm{CO}$ concentration up to $30 \mathrm{v} / \mathrm{o}$ at 120 and $180^{\circ} \mathrm{C}$, and by Dahr et al. ${ }^{10}$ for CO concentration up to 8.7 $\mathrm{v} / \mathrm{o}$ in the temperature range from 110 to $190^{\circ} \mathrm{C}$. Results similar to ours were reported. From the linear portions of current-potential curves, the fractional coverage of the re- active sites by carbon monoxide can be calculated using the following equation ${ }^{9,10}$

$$
\theta_{\mathrm{CO}}=1-\left[i_{\mathrm{CO}} / i_{\mathrm{H}_{2}}\right]^{1 / 2}
$$

The calculated coverage at both 150 and $130^{\circ} \mathrm{C}$ from Fig. $2 \mathrm{a}$ and $3 \mathrm{a}$ were found to be linear with respect to the natural logarithm of the ratio $[\mathrm{CO}] /\left[\mathrm{H}_{2}\right]$, as shown in Fig. 4. In this figure is also shown the results from Dahr et al. ${ }^{10}$ for both of the above-mentioned temperatures using a carbon-supported platinum electrode with a platinum loading of $0.4 \mathrm{mg} / \mathrm{cm}^{2}$ (which should be compared to $0.5 \mathrm{mg} / \mathrm{cm}^{2}$ in the present work).

To evaluate the effect of the $\mathrm{O}_{2}$ addition to a mixture of $\mathrm{CO}$ and hydrogen at different temperatures, a series of polarization measurements have been performed with different oxygen additions. Figure $2 b$ shows the polarization curves at $150^{\circ} \mathrm{C}$ for hydrogen containing $5 \mathrm{v} / \mathrm{o} \mathrm{CO}$ in the presence of oxygen at concentrations of 5,10 , and $25 \mathrm{v} / \mathrm{o}$, respectively. It can be seen that adding oxygen to the $\mathrm{CO}$ containing gas mixture has, in general, a very positive effect. For example, at a current density of $350 \mathrm{~mA} / \mathrm{cm}^{2}$ the overpotential for the $\mathrm{H}_{2} / \mathrm{CO} / \mathrm{O}_{2}$ mixture (85:5:10 v/o) drops $69 \mathrm{mV}$ compared with the mixture without $\mathrm{O}_{2}$ addition (i.e., from $145 \mathrm{mV}$ to $76 \mathrm{mV}$ ).

At a temperature of $130^{\circ} \mathrm{C}$, a similar effect was observed, as seen from Fig. 3b. When oxygen (corresponding to $3 \mathrm{v} / \mathrm{o}$ ) was injected into the mixture of hydrogen (corresponding to $96.5 \mathrm{v} / \mathrm{o}$ ) and carbon monoxide (corresponding to $0.5 \mathrm{v} /$ o), a significant decrease in overpotential occurred. With 5 v/o oxygen in the hydrogen stream, no significant potential loss was observed for a gas mixture containing up to $0.5 \mathrm{v} / \mathrm{O} \mathrm{CO}$, which is far more than the tolerance at this temperature without the presence of oxygen.

A similar effect has been demonstrated at 100 and $80^{\circ} \mathrm{C}$ in $100 \mathrm{v} / 0 \mathrm{H}_{3} \mathrm{PO}_{4}$ electrolyte, see Fig. 5 and 6 . At $100^{\circ} \mathrm{C}$, and with an oxygen content of $5 \mathrm{v} / \mathrm{o}$, it is shown that up to $0.2 \mathrm{v} / \mathrm{o}$ CO can be tolerated without a significant potential loss compared to that for pure $\mathrm{H}_{2}$.

At $80^{\circ} \mathrm{C}$ (see Fig. 6), when 5 v/o $\mathrm{O}_{2}$ was added to the gas mixture containing $0.1 \mathrm{v} / \mathrm{o} \mathrm{CO}$, the CO-free potential performance could almost be restored. For example, at a current density of $400 \mathrm{~mA} / \mathrm{cm}^{2}$, the overpotential for the hydrogen containing $0.1 \mathrm{v} / \mathrm{o} \mathrm{CO}$ and $5 \mathrm{v} / \mathrm{o} \mathrm{O}$ is only about 13 $\mathrm{mV}$ higher than that for the CO-free hydrogen.

It has been known from the methanol reforming research that the residue carbon monoxide in the $\mathrm{H}_{2} / \mathrm{CO}_{2}$ output mixture can be further removed by passing the reformed gases with small additions of oxygen over platinum on an

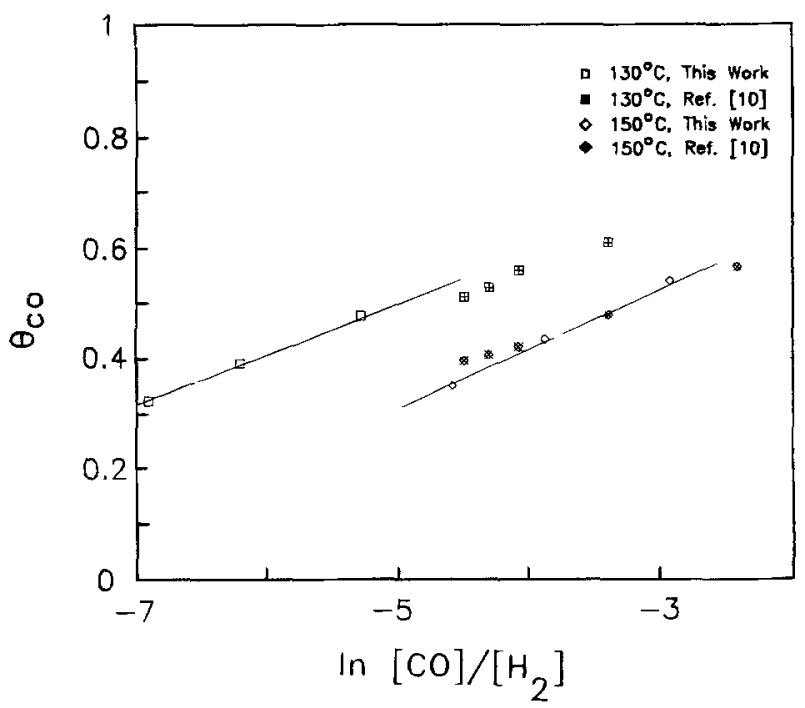

Fig. 4. Calculated fractional coverage of the catalyst surface by carbon monoxide, $\theta_{\mathrm{co}}$, for different $\mathrm{CO}$ concentrations at 130 and $150^{\circ} \mathrm{C}$. 


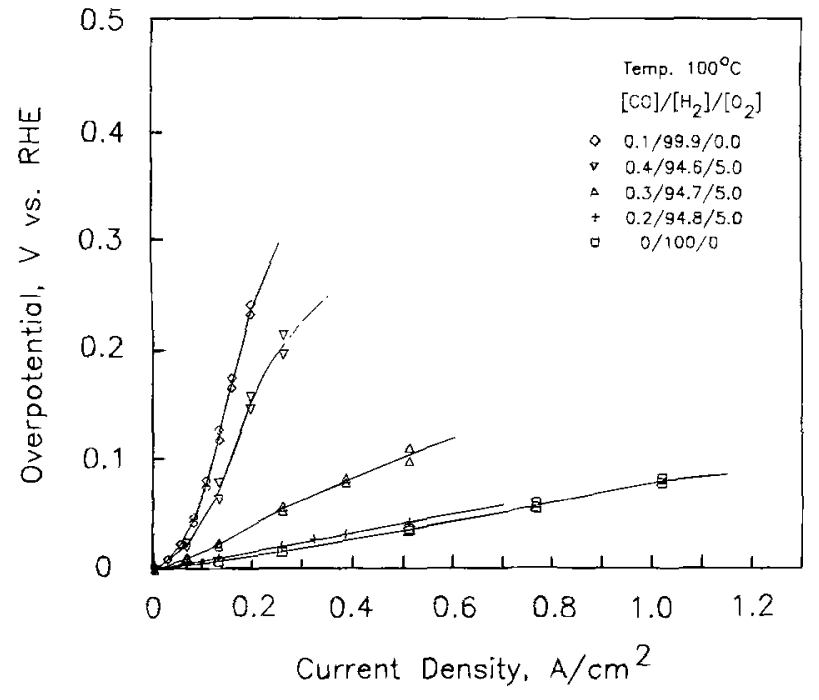

Fig. 5. Polarization curves for hydrogen oxidation in $100 \mathrm{w} / \mathrm{o}$ $\mathrm{H}_{3} \mathrm{PO}_{4}$ at $100^{\circ} \mathrm{C}$ with hydrogen containing $\mathrm{CO}$ in the presence of $\mathrm{O}_{2}$.

alumina catalyst at about $150^{\circ} \mathrm{C} .{ }^{15}$ Similar results were obtained at $80^{\circ} \mathrm{C}$ in a solid polymer electrolyte. ${ }^{13}$

It has been shown in the present work that the idea of adding oxygen is also effective for a carbon-supported platinum gas diffusion electrode in $100 \mathrm{w} / \mathrm{o}$ phosphoric acid electrolyte. Throughout the temperature range from 150 to $80^{\circ} \mathrm{C}$, oxidation of carbon monoxide by molecular oxygen occurs. The chemistry of the $\mathrm{CO}$ oxidation by molecular oxygen at temperatures as low as $80^{\circ} \mathrm{C}$ is not clearly understood yet. It seems that the carbon monoxide is more strongly absorbed than hydrogen on the active sites of the platinum catalyst. When oxygen is present, the CO oxidation may take place with the help of the platinum catalyst. Compared with the methanol reforming process, the presence of hydrogen ions from the acid electrolyte and

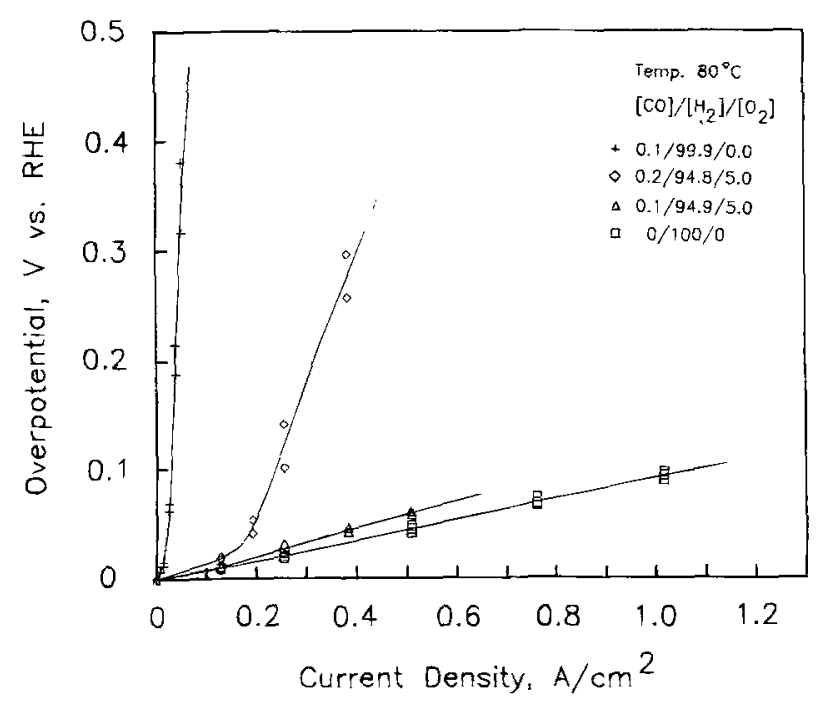

Fig. 6. Polarization curves for hydrogen oxidation in $100 \mathrm{w} / \mathrm{o}$ $\mathrm{H}_{3} \mathrm{PO}_{4}$ at $80^{\circ} \mathrm{C}$ with hydrogen containing $\mathrm{CO}$ in the presence of $\mathrm{O}_{2}$. the electric field applied at the electrode/acid/gas interface may also have some effects.

\section{Conclusions}

The hydrogen oxidation has been studied on a carbonsupported platinum gas diffusion electrode in a phosphoric acid electrolyte in the presence of carbon monoxide and oxygen. The poisoning effect of carbon monoxide contained in the gas was investigated and found to be very temperature dependent in the temperature range from 80 to $150^{\circ} \mathrm{C}$. Throughout the temperature range, the potential loss due to $\mathrm{CO}$ poisoning can be reduced to a great extent by injection of small amounts of gaseous oxygen into the hydrogen-carbon monoxide mixture. By adding $5 \mathrm{v} / 0$ oxygen, an almost $\mathrm{CO}$-free performance can be obtained for carbon monoxide concentrations up to $0.5 \mathrm{v} / \mathrm{o} \mathrm{CO}$ at $130^{\circ} \mathrm{C}, 0.2 \mathrm{v} / \mathrm{o}$ $\mathrm{CO}$ at $100^{\circ} \mathrm{C}$, and $0.1 \mathrm{v} / \mathrm{o} \mathrm{CO}$ at $80^{\circ} \mathrm{C}$, respectively.

\section{Acknowledgments}

The authors are grateful to the Danish Ministry of Energy, Haldor Topsøe A/S, and Elsam for their financial support.

Manuscript submitted June 28, 1994; revised manuscript received May 2, 1995.

\section{REFERENCES}

1. O. Wolter and J. Heitbaum, Ber. Bunsenges. Phys. Chem., 88, 6, (1984).

2. K. Kunimatsu, W. G. Golden, H. Seki, and M. R. Philpott, Langmuir, 1, 245 (1985); ibid., 2, 464 (1986).

3. B. Beden, N. Collas, C. Lamy, J. M. Leger, and V. Solis, Surf. Sci., 162, 789 (1985).

4. J. M. Leger, B. Beden, and C. Lamy, J. Electroanal. Chem., 170, 305, (1984).

5. N. Collas, B. Beden, J. M. Leger, and C. Lamy, ibid., 186, 287 (1985).

6. M. Watanabe and S. Motoo, ibid., 206, 197, (1986).

7. S. A. Bilmes, N. R. De Tacconi, and A. J. Arvia, ibid., 143, 179 (1983).

8. S. A. Bilmes and A. J. Arvia, ibid., 198, 137 (1986).

9. H. P. Dahr, L. G. Christner, A. K. Kush, and H. C. Maru, This Journal, 133, 1574 (1986).

1.0. H. P. Dahr, L. G. Christner, and A. K. Kush, ibid., 134, 3021 (1987)

11. H. R. Kunz, in Electrode Materials and Processes for Energy Conversion and Storage, J. D. E. McIntyre, S. Srinivasan, and F. G. Will Editors, PV 77-6, p. 607, The Electrochemical Society Proceedings Series, Princeton, NJ (1977).

12. A. P. Fickett, ibid., p. 546

13. L. G. Christner and P. N. Ross, in Proceedings of Workshop on Electrocatalysis Fuel Cell Reactions, p. 40, Brookhaven National Laboratory, Upton, NY (1978).

14. J. O'M. Bockris and A. J. Appleby, Energy, 11, 95 (1986).

15. N. E. Vanderborgh, J. Guante, R. E. Dean, Jr, and R. D. Sutton, Paper presented at 1988 Fuel Cell Seminar, Long Beach, CA, Oct. 23-26, 1988.

16. S. Gottesfeld and J. Pafford, This Journal, 135, 2651 (1988).

17. X. Gang, H. A. Hjuler, C. Olsen, R. W. Berg, and N. J. Bjerrum ibid., 140, 896 (1993).

18. L. Qingfeng, X. Gang, H. A. Hjuler, R. W. Berg, and N. J. Bjerrum, ibid., 141, 3114 (1994).

19. J. Kosek, N. Kackley, and A. LaConti, in Proceedings of 24th Intersociety Energy Conversion Engineering Conference, Vol. 3, p. 1581 (1989).

20. P. Stonehart, Int. J. Hydrogen Energy, 9, 921 (1984). 